\title{
EFFECT OF CARBENECILLIN AND CEFOTAXIME ON CALLUS INDUCTION AND DEVELOPMENT SOMATIC EMBRYOS OF MALAYSIAN INDICA RICE MR219
}

\author{
Zuraida Ab Rahman ${ }^{1} 凹$, Ayu Nazreena Othman ${ }^{1}$, Amirah Balqis Amir Amran ${ }^{2}$, Nur Najwa Arifah \\ Basiron ${ }^{1}$, Norliza Abu Bakar ${ }^{1}$, Zulkifli Ahmad Seman ${ }^{1}$ \\ ${ }^{1}$ Biotechnology and Nanotechnology Research Centre, Malaysian Agricultural Research and Development \\ Institute, MARDI HQ, Persiaran MARDI-UPM, 43400 Serdang Selangor, Malaysia \\ ${ }^{2}$ School of Agriculture Science and Biotechnology, Faculty of Bioresources and Food Industry, University \\ Sultan Zainal Abidin, Besut Campus, 22200, Besut, Terengganu, Malaysia
}

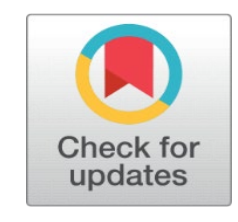

Received 18 January 2022

Accepted 22 February 2022

Published 05 March 2022

CorrespondingAuthor

Zuraida Ab Rahman,

azuraida@mardi.gov.my

DOI

10.29121/granthaalayah.v10.i2.2022 .4509

Funding: This research received no specific grant from any funding agency in the public, commercial, or not-for-profit sectors.

Copyright: (C) 2022 The Author(s). This is an open access article distributed under the terms of the Creative Commons Attribution License, which permits unrestricted use, distribution, and reproduction in any medium, provided the original author and source are credited.

\section{ABSTRACT}

Carbenicillin and cefotaxime, two antibiotics routinely employed to exclude Agrobacterium tumefaciens during plant transformation, were studied for their effects on callus growth and the formation of somatic embryos. Antibiotics were tested to see how they responded to the regeneration of Malaysian indica rice cv. MR219. In a preliminary study, callus fresh weight gain appeared to be improved in media containing $200 \mathrm{mg} / \mathrm{L}$ carbenicillin and 300-400 mg/L cefotaxime but was severely hindered in media containing higher concentrations. Somatic embryos were discovered in greater numbers in the medium containing $200 \mathrm{mgl}-1$ carbenicillin or $300 \mathrm{mgl}-1$ cefotaxime, at 76 and 71, respectively. It was possible that these antibiotics showed a positive response on somatic embryos development when compared to those without antibiotics. Carbenicillin and cefotaxime concentrations greater than $300 \mathrm{mg} / \mathrm{L}$ should not be utilized for the process.

Keywords: Callus Induction, Carbenicillin and Cefotaxime, MR219

\section{INTRODUCTION}

During the recent decade, significant progress has been made in plant transformation, with Agrobacterium mediation being used in several cases Nauerby et al. (1997). Antibiotics have become commonplace in plant tissue culture for Agrobacterium-mediated DNA transfer. Antibiotics are given to culture media for reduce the growth of Agrobacterium that could interfere with plant regeneration. They also can identify transformants with antibiotic resistance that is co-transferred with the gene of interest Shaw et al. (1983). Although many antibiotics have been described for effective control of Agrobacterium cells, carbenicillin and cefotaxime, both belonging to the b-lactam group, have minimal toxicity on most plant tissues and have thus become the most widely accepted in Agrobacterium-mediated transformation Mathias and Boyd (1986). Both antibiotics, however, have been shown to have plant hormone-like effects in cultured plant tissues and may alter somatic embryogenesis in a variety of plant species Nauerby et al. (1997). Therefore, the effects of carbenicillin and cefotaxime on callus proliferation and somatic embryos initiation during the plant regeneration process of Malaysian indica rice cv.MR219 were examined. 


\section{MATERIAL AND METHODS}

\subsection{PLANT MATERIAL AND CALLUS GROWTH}

Mature seeds of the rice variety MR 219 were dehulled and sterilized by immersion in $100 \%$ ethanol for 1-2 min, then in 1\% Vicon for $30 \mathrm{~min}$, rinsed three times in sterile, distilled water and followed by immerse in $100 \%$ Clorox supplemented for $40 \mathrm{~min}$. After being rinsed three times in sterile distilled water, the seeds were placed on corresponding embryogenic callus induction media, MS medium supplemented with $10 \mathrm{mg} / \mathrm{L} \mathrm{NAA}$ and $1 \mathrm{mg} / \mathrm{L} \mathrm{2,4-D} 30 \mathrm{~g} \mathrm{l}-1$ sucrose and $0.8 \%$ agar, at $\mathrm{pH}$ 5.7. Primary Calli obtained after 3 weeks of culture. The Calli were then sub-cultured onto callus induction media containing different concentration of cefotaxime or carbenicillin at $100-500 \mathrm{mg} / \mathrm{L}$, respectively. Calli were then placed in the dark at $26 \mathrm{C} \pm 2$ for 4 weeks before fresh weight of Calli weighted.

\subsection{SOMATIC EMBRYOS PRODUCTION}

Selected embryogenic Calli from previous experiment that treated with antibiotic were cultured on pre-regeneration MS media supplemented with $10 \mathrm{mg} / \mathrm{L}$ ABA then incubated in dark at $25 \pm 2^{\circ} \mathrm{C}$ for 6 -8 weeks and were sub-cultured every 2 weeks. To determine the effects of the antibiotics on production of somatic embryos, carbenicillin and cefotaxime were added to the pre-regeneration medium at concentrations of $0,100,200,300,400$ and $500 \mathrm{mg} / \mathrm{L}$. All antibiotics were added to the regeneration medium after autoclaving. The effective concentrations of antibiotics were determined. The forming of somatic embryos was collected and recorded. he experiments was carried out three times, with each treatment consisting of ten embryogenic calluses.

\section{RESULTS AND DISCUSSION}

\subsection{CALLUS GROWTH}

As shown in Figure 2, maximum callus proliferation was formed on medium supplemented with $200 \mathrm{~g} / \mathrm{L}$ carbenicillin $(0.42 \mathrm{~g})$ or $300 \mathrm{mg} / \mathrm{L}$ cefotaxime $(0.49 \mathrm{~g})$ (Figure 1a). Antibiotic strongly reduced rice callus proliferation if we applied it more than $300 \mathrm{mg} / \mathrm{L}$. In the presence of $400 \mathrm{mg} / \mathrm{L}$ carbenicillin or cefotaxime, a slightly inhibitory effect was seen (Figure $1 \mathrm{~b}$ ). The present of both antibiotics more than $300 \mathrm{mg} / \mathrm{L}$ decreased the fresh weight of callus up to $0.19 \mathrm{~g}$ (carbenicillin) and $0.26 \mathrm{~g}$ (cefotaxime). The highest dose of both carbenicillin and cefotaxime (500 $\mathrm{mg} / \mathrm{L}$ ) completely inhibited (Figure 1c) callus proliferation compared to control (Figure 2). Carbenicillin clearly affected the proliferation capacities of Calli as compared to cefotaxime
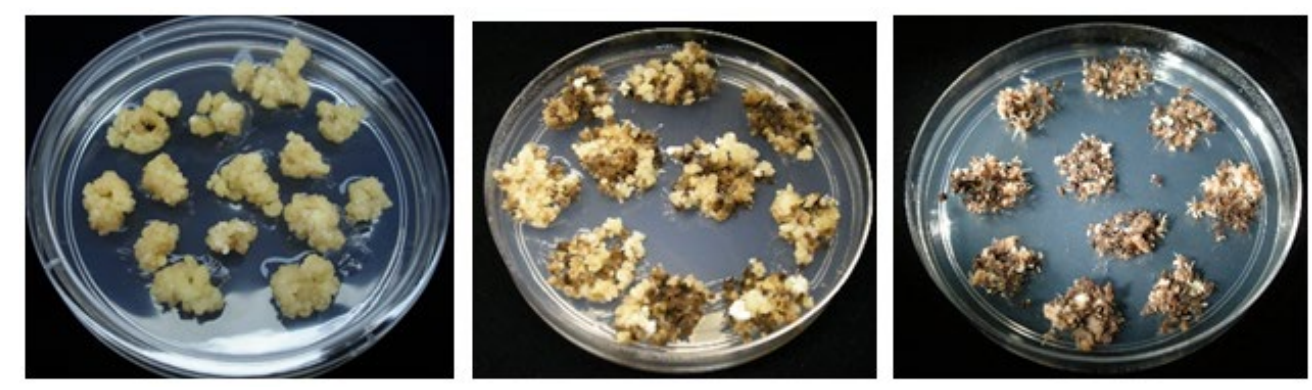

Figure 1 Callus induction that cultured on media containing $300 \mathrm{mg} / \mathrm{L}$ cefotaxime (a), $400 \mathrm{mg} / \mathrm{L}$ cefotaxime (b) abd $500 \mathrm{mg} / \mathrm{L}$ cefotaxime (c) 


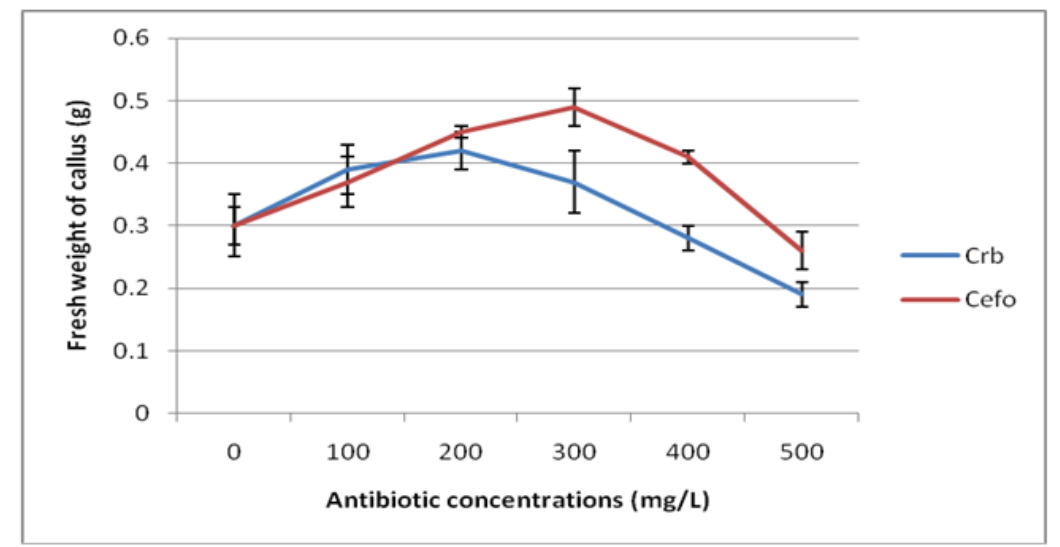

Figure 2 Effect of different concentration of carbenicillin and cefotaxime of callus growth of indica rice cv MR219 after 3-4 weeks on callus induction medium

\subsection{SOMATIC EMBRYOGENESIS}

When the cultures were exposed to antibiotic at different concentration, similar trend in number somatic embryos was observed in rice. The number of somatic embryos decreased when the concentration of cefotaxime was increased up to 500 $\mathrm{mg} / \mathrm{L}$, after which it started to decline. The frequency of somatic embryos on preregeneration medium was lowest at a higher dosage of both antibiotics (500 mgl-1), i.e., 21 in the present carbenicillin and 13 in cefotaxime. However, the medium containing $200 \mathrm{mg} / \mathrm{L}$ carbenicillin and $300 \mathrm{mg} / \mathrm{L}$ cefotaxime had the highest incidence of somatic embryos, with 76 and 71 somatic embryos, respectively. It was fascinating to see that using carbenicillin $(100-200 \mathrm{mg} / \mathrm{L})$ increased not only callus proliferation but also somatic embryo formation when compared to the control (Figure 3). This revealed that different concentrations of antibiotic used showed a significant difference on somatic embryogenesis. Overall, the highest browning 60 $\%$ and $30 \%$ in $500 \mathrm{mg} / \mathrm{L}$ of carbenicillin and cefotaxime, respectively (Figure 4).

Previously, Yepes and Aldwinckle (1994) found that 200mg/L cefotaxime produced more shoots per culture when compared to control, and application higher than that the rate of shoot multiplication and elongation was inhibited. The reduction of ethylene production in the cultures by cefotaxime, which is favourably correlated with plantlet differentiation, could be linked to an increase in the number of micro tillers Pius et al. (1993). The higher the concentration of antibiotics supplied; the percentage of browning continues to increase. This indicates that the optimal level should be used to prevent the occurrence of browning. The use of a higher dosage of antibiotic (100 mg/L) in wheat mature embryos accelerated callus browning and hindered subsequent regeneration Yu and Wei (2008). 


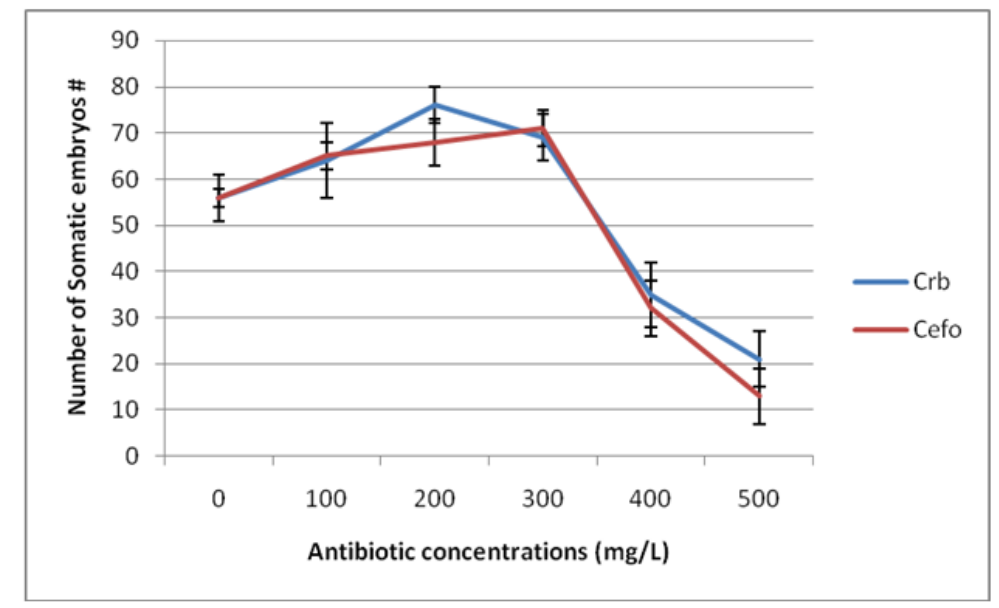

Figure 3 Effect of different concentration of carbenicillin and cefotaxime on initiation of somatic embryos of indica rice cv MR219 after 7-8 weeks on pre-regeneration medium

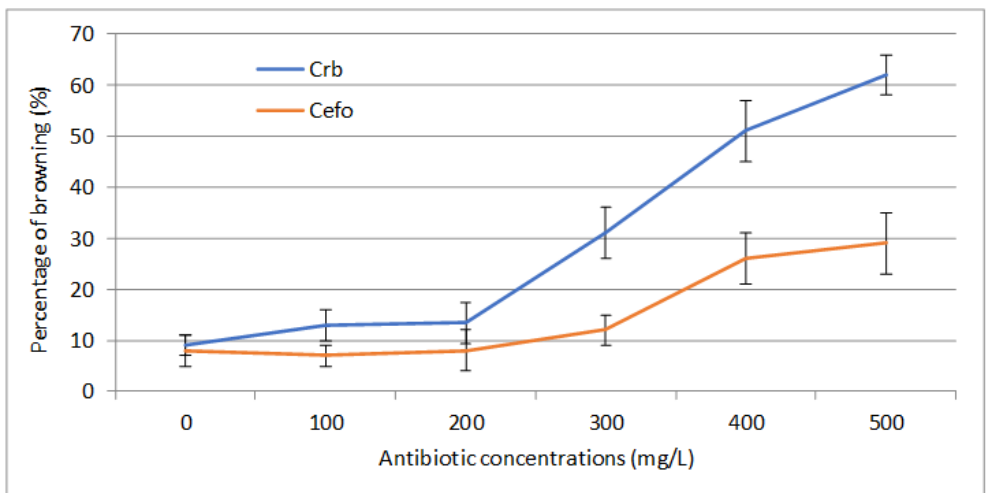

Figure 4 Effect of different concentration of carbenicillin and cefotaxime on percentage of browning appearance of indica rice cv MR219 after 7-8 weeks on pre-regeneration medium

\section{CONCLUSION}

As indicated by enhanced callus fresh weight and somatic embryo initiation in the current study, carbenicillin (100-200 mg/L) and cefotaxime $(100-300 \mathrm{mg} / \mathrm{L})$ boost the development of the Indica rice tissue culture system. Carbenicillin and cefotaxime were discovered to be antibacterial as well as having an effect on the initiation of somatic embryogenesis in this investigation. As shown by the increased callus fresh weight and initiation of somatic embryos in the current study, carbenicillin (100-200 mg/L) and cefotaxime (100-300 $\mathrm{mg} / \mathrm{L})$ promote the development of the indica rice tissue culture system. Carbenicillin and cefotaxime were found to have both antibacterial effects and an effect on the initiation of somatic embryogenesis in this study. When $200 \mathrm{mg} / \mathrm{L}$ carbenicillin or $300 \mathrm{mg} / \mathrm{L}$ cefotaxime was used, somatic embryogenesis of indica rice MR219 was found to be most successful.

\section{REFERENCES}

Mathias, T.J. and L.A. Boyd. (1986). Cefotaxime stimulates callus growth, embryogenesis and regeneration in hexaploid bread wheat (Triticum 
aestivum L. EM. Thell). Plant Sci.46 : 217-233. Retrieved from https://doi.org/10.1016/0168-9452(86)90195-0

Nauerby, B., K. Billing, and R. Wyndaele. (1997). Influence of the antibiotic timentin on plant regeneration compared to carbenicillin and cefotaxime in concentrations suitable for elimination of Agrobacterium tumefaciens. Plant Sci. 123 : 169-177. Retrieved from https://doi.org/10.1016/S01689452(96)04569-4

Pius J, George L, Eapen S, Rao PS (1993) Enhanced plant regeneration in pearl millet (Pennisetum americanum) by ethylene inhibitors and cefotaxime. Plant Cell Tissue Org Cult 32 : 91-96. Retrieved from https://doi.org/10.1007/BF00040121

Shaw, C.H., J. Leemans, M. Van Montagu, and J. Schell. (1983). A general method for the transfer of cloned genes to plant cells. Gene $23: 315-330$. Retrieved from https://doi.org/10.1016/0378-1119(83)90021-5

Yepes LM, Aldwinckle HS (1994) Micropropagation of thirteen Malus cultivars and rootstocks and effect of antibiotics on proliferation. Pl Growth Regulation 15 : 55-67. Retrieved from https://doi.org/10.1007/BF00024677

$\mathrm{Yu}$ Y. and Z.-M. Wei (2008). Influences of cefotaxime and carbenicillin on plant regeneration from wheat mature embryos. Biologia Plantarum volume 52, pages553-556 Retrieved from https://doi.org/10.1007/s10535-008-01091 